\title{
Impact of large-scale natural physical disturbance on the diversity of deep-sea North Atlantic nematodes
}

\author{
P. J. D. Lambshead ${ }^{1, *}$, J. Tietjen ${ }^{2}$, A. Glover ${ }^{1}$, T. Ferrero ${ }^{1}$, D. Thistle ${ }^{3}$, A. J. Gooday ${ }^{4}$ \\ ${ }^{1}$ Department of Zoology, The Natural History Museum, London SW7 5BD, United Kindom \\ ${ }^{2}$ Department of Biology, City College of New York, New York, New York 10031 \& Division of Invertebrates, \\ American Museum of Natural History, New York, New York 10024, USA \\ ${ }^{3}$ Department of Oceanography, Florida State University, Tallahassee, Florida 32306-3048, USA \\ ${ }^{4}$ Southampton Oceanography Centre, George Deacon Division for Ocean Processes, Empress Dock, \\ Southampton SO14 3ZH, United Kindom
}

\begin{abstract}
Nematode alpha diversity from 3 physically disturbed sites in the deep North Atlantic was compared with reference sites. Nematode diversity at the HEBBLE benthic storm site was statistically, and significantly, lower than at reference sites. Nematode diversity at the Madeira Abyssal Plain site, which was subject to a turbidite dated at $930 \mathrm{BP}$, also showed a significantly lower diversity than reference sites. However, limited data suggest that diversity was not low at a Venezuela Basin turbidite site. The difference in nematode diversity between the 2 turbidite sites is ascribed to a long term change in sediment conditions at the Madeira site. The Venezuela Basin turbidite site has a sedimentation rate greater than the Maderia site by 1 to 2 orders of magnitude, and this was reflected in the sediment profiles. Another possibility is that the Venezuela Basin turbidite is considerably older, by at least $1000 \mathrm{yr}$, than the Madeira turbidite, allowing more time for recolonisation. The data suggest that deep-sea nematode diversity may be affected by physical disturbance but that deep-sea nematodes, like their shallow counterparts, are more robust than macrofauna such as polychaetes to such impacts.
\end{abstract}

KEY WORDS: Physical Disturbance $\cdot$ Deep Sea $\cdot$ North Atlantic $\cdot$ Nematodes

\section{INTRODUCTION}

The last 3 decades of the 20th century have seen a substantial increase in the number of investigations that involve analysis of the biodiversity of deep-sea nematodes, particularly in the North Atlantic. This accumulation of results from individual projects over 3 decades has presented an opportunity to study deepsea nematode biodiversity over large distances. Prior to 1980 , little was known about the diversity distributions of deep-sea nematodes over larger scales, let alone the processes underlying such patterns. Deep-

\footnotetext{
*E-mail: pjdl@nhm.ac.uk
}

sea nematology has had a slow inception because (1) the limited numbers of marine nematologists have, understandably, tended to focus on shallow waters where experimentation is possible, (2) quantative sampling was not possible until the development of the spade-box corer and, especially, the Barnett multicorer, and (3) the primitive state of deep-sea nematode taxonomy makes biodiversity analysis of samples difficult and laborious. Deep-sea nematode research is still in the stage of identifying statistically significant patterns and inductively associating these with ecological, biogeographical and historical properties of the environment to develop hypotheses of the mechanisms that control biodiversity. Developing technologies to test these hypotheses will be expensive and time consum- 
ing. It is, therefore, important to extract as much information from pattern analyses of current data as possible to synthesise hypotheses that will be productive for further testing, given the limited resources available.

Using an accumulated deep-sea nematode database, Boucher \& Lambshead (1995) investigated the relationship between nematode diversity and depth, and Lambshead et al. (2000) analysed latitudinal diversity gradients in the deep North Atlantic Ocean. Both studies concluded that productivity was an important factor in producing nematode biodiversity and species richness patterns, respectively, over large distances.

Current ecological theory suggests that both productivity and disturbance influence biodiversity patterns over ecological time scales (Huston 1994). Experimentation on shallow-water nematodes has suggested that both physically (Schratzberger \& Warwick 1998) and biologically generated disturbance (Austen et al. 1998) can cause modest changes in nematode diversity. The impact of physical disturbance on deep-sea nematodes has been investigated only to a limited degree and the effect of biological disturbance has not been investigated at all. Lambshead et al. (1994) compared the diversity of bathyal nematodes in the Rockall Trough with the San Diego Trough. San Diego Trough is a physically undisturbed area whereas Rockall Trough has sufficient moderate physical disturbance in the form of water currents sufficient to ripple the sediment and affect polychaete diversity (Paterson \& Lambshead 1995). Lambshead et al. (1994) could find no evidence that nematode diversity, unlike polychaetes, was influenced by moderate water current disturbance. Nevertheless, Boucher \& Lambshead (1995) hypothesised that low diversity in estuarine and hadal nematode communities was partly a result of physical distur- bance. Glover et al. (2001) reported that large-scale physical disturbance had long lasting influences on deep-sea polychaete diversity. Lambshead et al. (2000) suggested that there was some evidence for reduced nematode diversity in deep-sea sites affected by largescale physical disturbance with a higher impact than the energy currents found in the Rockall Trough.

This paper will analyse the available data to determine (1) whether the available abyssal nematode biodiversity data show evidence of the effects of largescale physical disturbance, and (2) whether analysis of a turbidite site can give some time frame for recovery from disturbance. To achieve this, it will use a database sourced from 4 research programmes that identified more than 7000 deep-sea nematodes in 43 samples from 9 locations.

\section{METHODS}

Sites. The sites utilised for this study have been described in a number of publications that are listed below; accordingly, only brief descriptions will be given here. The data sets were the same as those used by Boucher \& Lambshead (1995) and Lambshead et al. (2000), see Table 1 and references for full description of sites. The reference sites include the Porcupine Abyssal Plain (PAP, Rice \& Lambshead 1994, Thistle et al. 1995), the Hatteras Abyssal Plain (HAP, Tietjen 1989) and the Venezuela Basin Stns 1 \& 3 (VB1, 3, Tietjen 1984). The disturbed sites include HEBBLE (Thistle \& Sherman 1985, Thistle et al. 1985, Thistle et al. 1995), the Madeira Abyssal Plain (MAP, Rice \& Lambshead 1994, Thistle et al. 1995) and the Venezuela Basin Stn 2 (VB2, Tietjen 1984).

Table 1. The sites, their physical characteristics, mean and standard deviation of the ES(51) rarefaction statistics for the cores, species count from the site, and the number of cores and nematodes on which the analysis is based. SD: standard deviation

\begin{tabular}{|c|c|c|c|c|c|c|c|c|}
\hline Station & $\begin{array}{l}\text { Latitude } \\
\left({ }^{\circ} \mathrm{N}\right)\end{array}$ & $\begin{array}{l}\text { Depth } \\
\text { (m) }\end{array}$ & $\begin{array}{l}\text { Sedimentation } \\
\text { rate }\left(\mathrm{cm} \mathrm{kyr}^{-1}\right)\end{array}$ & $\begin{array}{l}\text { Mean } \\
\text { ES(51) }\end{array}$ & SD & $\begin{array}{l}\text { Species } \\
\text { count }\end{array}$ & $\begin{array}{l}\text { Ind. (cores/ } \\
\text { nematodes) }\end{array}$ & Source \\
\hline \multicolumn{9}{|l|}{ Reference Sites } \\
\hline $\begin{array}{l}\text { Porcupine Abyssal Plain } \\
\text { (1989) }\end{array}$ & 49 & 4850 & 3.0 & 28.80 & 2.14 & 131 & $6 / 1256$ & Santos et al. (1994) \\
\hline $\begin{array}{l}\text { Porcupine Abyssal Plain } \\
\text { (1991) }\end{array}$ & 49 & 4850 & 3.0 & 32.92 & 1.11 & 156 & $6 / 1428$ & Santos et al. (1994) \\
\hline Hatteras Abyssal Plain & 32 & 5411 & & 29.95 & 1.05 & 88 & $2 / 507$ & \\
\hline Venezuela Basin 1 & 15 & 3858 & 2.9 & 27.21 & 2.04 & 54 & $2 / 309$ & Cole et al. (1985) \\
\hline Venezuela Basin 3 & 13 & 3517 & 4.6 & 32.13 & 0.98 & 85 & $2 / 425$ & Cole et al. (1985) \\
\hline \multicolumn{9}{|l|}{ Disturbed sites } \\
\hline HEBBLE Stn 1 & 40 & 4626 & & 24.94 & 2.98 & 133 & $8 / 1331$ & \\
\hline HEBBLE Stn 2 & 40 & 4626 & & 25.26 & 1.40 & 124 & $9 / 1152$ & \\
\hline Madeira Abyssal Plain & 31 & 4950 & $0.1-1.0$ & 25.39 & 1.21 & 78 & $6 / 578$ & Weaver \& Rothwell (1987) \\
\hline Venezuela Basin 2 & 13 & 5054 & 7.2 & 31.78 & 2.19 & 73 & $2 / 270$ & Cole et al. (1985) \\
\hline
\end{tabular}




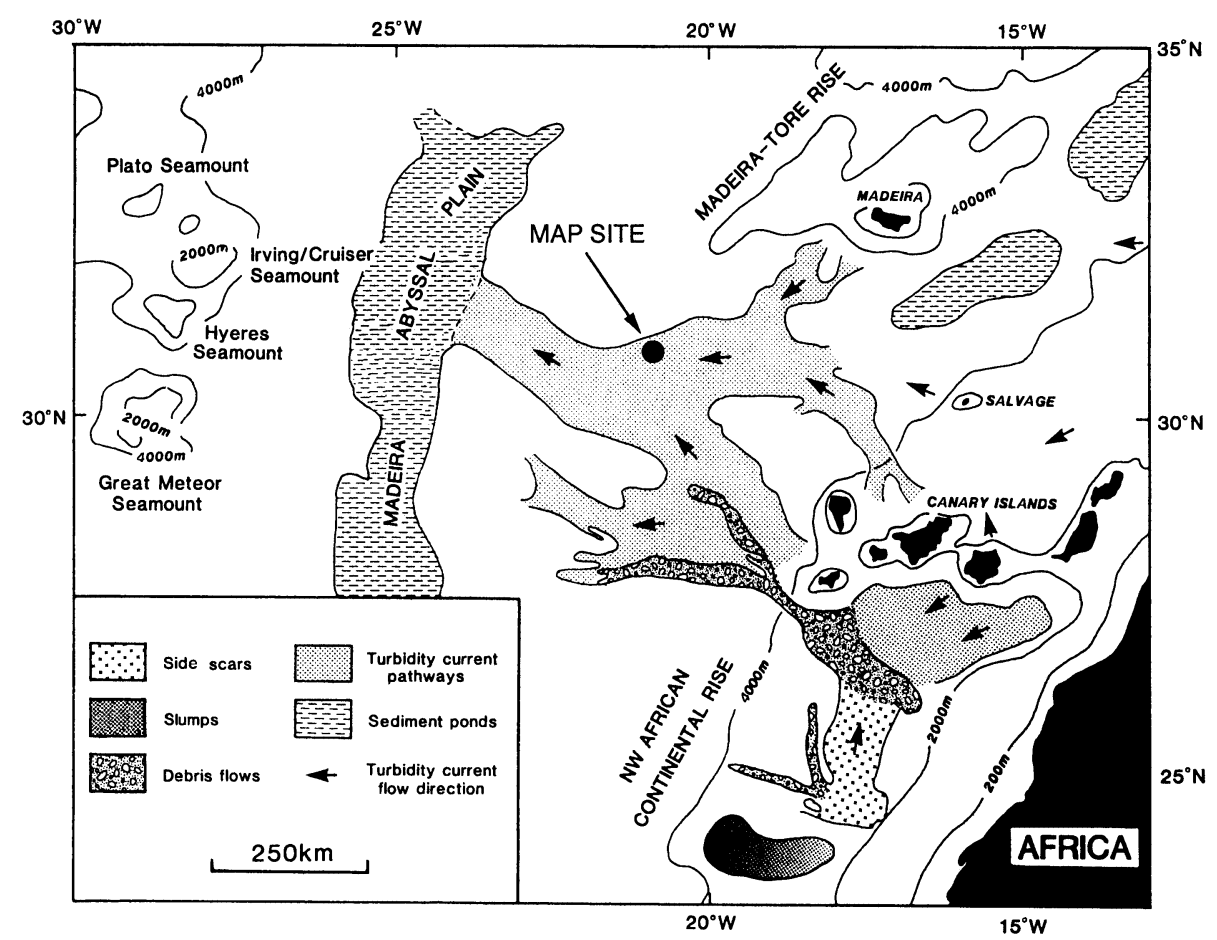

Fig. 1. Map of the Madeira Abyssal Plain (MAP) turbidite region showing the location of the collecting site and the extent of the turbidite (adapted from de Lange et al. 1987)

The PAP site is located to the southwest of Ireland at $48^{\circ} 50^{\prime} \mathrm{N}, 16^{\circ} 30^{\prime} \mathrm{W}$. It receives a seasonal input of aggregated phytodetritus. The HAP site is at $32^{\circ} 29.6^{\prime} \mathrm{N}$, $70^{\circ} 21.0^{\prime} \mathrm{W}$. The sediments were hemipelagic, greybrown terrigenous silt clays with some fine Foraminifera remains.

The 3 sites from the Venezuela Basin represent 3 major sedimentary provinces (Richardson \& Young 1987). The pelagic site (VB1) is located at $15^{\circ} 07^{\prime} \mathrm{N}$ $69^{\circ} 22^{\prime} \mathrm{W}$. Sediments at this site consist primarily of foraminiferan tests, coccolith plates and pteropod shells. The turbidite site (VB2) is located at $13^{\circ} 45^{\prime} \mathrm{N}$ $67^{\circ} 22^{\prime} \mathrm{W}$. Sediments here consist of alternating layers of pelagic clays and coarse turbidite deposits. The main source of the non-carbonate sediments is discharge from the Orinoco and Amazon Rivers (Bowles \& Fleischer 1985). The deep Venezuela Basin is a low energy environment with restricted renewal at depth (Kinder et al. 1985). The hemipelagic site (VB3) is located at $13^{\circ} 30^{\prime} \mathrm{N} 64^{\circ} 45^{\prime} \mathrm{W}$. Sediments here are a mixture of terrestrially derived clay-size particles mixed with pelagic carbonate sediments. 'HEBBLE' in this paper refers to the stations used for the preliminary studies of the High Energy Benthic Boundary Layer Experiment (Holister \& Newell 1991). The stations are in a productive area, which suffers from benthic storms 8 to 10 times $\mathrm{yr}^{-1}$ when water velocities $10 \mathrm{~m}$ above the sediment reach 15 to $40 \mathrm{~cm} \mathrm{~s}^{-1}$
(Weatherly \& Kelly 1982). The MAP station (Fig. 1) lies on the distal part of turbidite deposits (Weaver \& Rothwell 1987). This area has been subject to many turbidite events during interglacial-glacial transitions, the last being dated to $930 \mathrm{BP}$. This most recent turbidite has covered the area of the station with displaced sediment to a depth of at least $90 \mathrm{~cm}$ (Thomson \& Weaver 1994).

Note that only samples judged adequately quantitative, i.e. from spade-box or deep-sea meiofauna corers, were employed.

Analysis. The nematodes used were identified in just 2 laboratories to ensure comparability given the primitive nature of deep-sea nematode taxonomy. Western Atlantic sample organisms were identified at the City College of New York and eastern Atlantic samples at The Natural History Museum, London. HEBBLE nematodes were originally identified into species at Florida State University, but the Florida collection was later taxonomically calibrated against the collections in The Museum.

The species-abundance data for each core were converted into rarefaction diversity indices using the methods of Sanders (1968) as modified by Hurlbert (1971), employing the BDPro program. Ecological diversity indices are widely used to detect disturbance when working at the alpha-diversity level, although their use is not without controversy, e.g. Gage \& May 
(1993). The rarefaction statistic ES(X) (Expected number of Species per $\mathrm{X}$ number of individuals) has the advantage of being robust to sample size. This is of paramount importance in a study of this kind where differently sized samples have been taken at different sites and organism abundance has also varied quite considerably from site to site. Rarefaction is not without disadvantages. There can be a problem of bias where organisms are aggregated in the sediments (Gray 2000, Lambshead et al. 2000), but these disadvantages are considered minor compared to the advantages of rarefaction in the context of this study. The expected number of species for a theoretical sample of 51 individuals was selected as the largest number that allowed the majority of cores to be compared.

Rarefaction data between sites were analysed by parametric 2 sample $t$-tests, using the Minitab program. The choice of reference sites for each of the supposed sites was governed by latitude. Lambshead et al. (2000) reported a positive species richness gradient from south to north through the North Atlantic up to $56^{\circ} \mathrm{N}$. This gradient was not detectable when a diversity index was employed as an alpha diversity measure. Nevertheless, the possibility of bias due to latitude was considered when choosing reference stations.

\section{RESULTS}

\section{HEBBLE}

The mean ES(51) for the 17 cores at the 2 HEBBLE stations had a significantly lower diversity than the reference sites, which bracketed HEBBLE by latitude to the north and south (PAP and HAP), Table 2. However, 12 of the 14 reference cores were taken from PAP.

Table 2. Comparison of the mean ES(51) diversity at HEBBLE, the Porcupine Abyssal Plain, the Hatteras Abyssal Plain and all reference sites

\begin{tabular}{|lccc|}
\hline Sites & No. of samples & Mean & SD \\
\hline HEBBLE & 17 & 25.11 & 2.21 \\
PAP/HAP & 14 & 30.73 & 2.52 \\
All Reference Sites & 18 & 30.49 & 2.61 \\
Comparison & $\mathrm{T}$ & $\mathrm{DF}$ & $\mathrm{P}$ \\
\hline HEBBLE vs & 6.52 & 26 & 0.0000 \\
$\begin{array}{l}\text { PAP/HAP } \\
\text { HEBBLE vs all }\end{array}$ & -6.60 & 32 & 0.0000 \\
reference sites & & & \\
\hline
\end{tabular}

Table 3. Comparison of the mean ES(51) diversity at the Madeira Abyssal Plain, all reference sites south of Madeira (S) and all reference sites

\begin{tabular}{|lccc|}
\hline Sites & No. of samples & Mean & SD \\
\hline MAP & 6 & 25.39 & 1.21 \\
S reference sites & 6 & 29.76 & 2.47 \\
All reference sites & 18 & 30.49 & 2.61 \\
Comparison & $t$ & $\mathrm{df}$ & $\mathrm{p}$ \\
\hline MAP vs S & -3.89 & 7 & 0.0061 \\
reference sites & & 18 & 0.0000 \\
MAP vs all & -6.47 & & \\
reference sites & & & \\
\hline
\end{tabular}

This is north of HEBBLE, so the possibility of bias due to the latitudinal species richness gradient had to be addressed. Accordingly, HEBBLE was compared to all the reference cores adding in 6 additional southern cores, some of which were more than $25^{\circ}$ south of HEBBLE. Again, a significantly lower diversity was found at HEBBLE. This second test is conservative, as the majority of the reference cores were found to the south of HEBBLE. The lower diversity, although statistically highly significant, was small with diversity being an ES(51) of approximately 25.1 as opposed to 30.5 .

\section{Madeira Abyssal Plain (MAP)}

The mean ES(51) for the 6 cores of MAP site was compared to the 6 reference cores that came from sites located to the south of MAP (Table 3). This is a conservative test, as any latitudinal bias would act to reduce the diversity of the southern cores. MAP cores showed significantly lower diversity than the reference cores but, again, the difference in diversity was modest. For completeness, the mean of the MAP cores was tested against the mean of all the reference cores, with a similar result.

\section{Venezuela Basin Site 2}

Only 2 cores were available from this site so statistical analysis would not be appropriate. However, the mean diversity for $\mathrm{ES}(51)$ of approximately 31.78 (Table 4) is higher than all the reference cores (30.49) or just the subset of southern reference sites (29.76). It may be concluded that the limited data show no evidence of low diversity at VB2. 
Table 4. ES(51) of the 2 samples from the Venezuela Basin Site 2

\begin{tabular}{|lccc|}
\hline Sites & No. of samples & Mean & SD \\
\hline VB2 & 2 & 31.78 & 2.19 \\
\hline
\end{tabular}

\section{DISCUSSION}

HEBBLE shows evidence of a low diversity, although the difference between HEBBLE and the reference stations is modest. The one feature that distinguished HEBBLE from the reference cores was the benthic storms reported at this site. Shallow water nematodes are known to be robust to physical disturbance, compared with macrofauna, but not immune as physical disturbance is known to cause modest changes in diversity (Schratzberger \& Warwick et al. 1998). The most likely explanation for HEBBLE having a statistically significant, slightly lower diversity than the reference stations are the benthic storms that are associated with this site.

Greater robustness of nematodes to physical disturbance than macrofauna probably explains why no reduction in nematode diversity caused by water currents was reported for Rockall Trough nematodes (Lambshead et al. 1994), despite the evidence of a physical impact on polychaete diversity at this site (Paterson \& Lambshead 1995). The Rockall water currents are less energetic than those found at HEBBLE.

The cores from MAP showed a similar nematode diversity to the HEBBLE area, and again the diversity was significantly less than reference sites. The most parsimonius explanation is that this low diversity was associated with the turbidite that impacted this area. The turbidite appears to have left an impression on nematode diversity patterns after almost $1000 \mathrm{yr}$ that is equal to repeated exposure to high-energy benthic storms: this result is intuitively surprising.

Turbidites are large-scale impacts and the Madeira turbidite covered a considerable area (Fig. 1). So it is possible that there has been insufficient time for nematodes to recolonise the impacted area. Data on the dispersal ability of deep-sea nematodes are lacking, but it may be relevant that this taxon lacks a dispersal larval phase. Polychaetes also display a low diversity at MAP (Glover et al. 2001), although it is not clear how many deep-sea polychaete species lack a larval dispersal phase. Without more information on deep-sea nematode dispersal mechanisms, it is impossible to assess the credibility of this explanation.

Another, more plausible, explanation is that the Madeira turbidite has caused a long-lasting change in sediment characteristics that is significant for nema- todes. Such a change might influence diversity. Etter \& Grassle (1992) showed that deep-sea macrofaunal diversity was correlated with sediment diversity and Tietjen (1976) discovered a link between deep-sea nematode diversity and sediment characteristics. This second hypothesis is further supported by sedimentation data. MAP has a low sedimentation rate of 0.1 to $1 \mathrm{~cm} \mathrm{kyr}^{-1}$ (Weaver \& Rothwell 1987). Only a thin layer of pelagic sedimentation, approximately 1 to $2 \mathrm{~mm}$ thick, could be seen in the cores above the turbidite layer (Gooday pers. obs.).

In contrast, the limited data from VB2, which has also been turbidite affected, show no evidence of an impact on diversity. The sedimentation rate at this site is $7.2 \mathrm{~cm} \mathrm{kyr}^{-1}$ and the turbidite is covered by a $14 \mathrm{~cm}$ layer of pelagic sediment (Cole et al. 1985) which is at least 2000 years old. There are 2 key differences between VB2 sediments and MAP station sediments. The first is that the VB tubidite was twice as old, allowing greater time for recolonisation. The second is that the nematodes at VB2 were inhabiting pelagic sediments that had been deposited since the last turbidite, whereas the nematode fauna at MAP were, apart from a superficial layer, in turbidite sediments. Either or both of these factors might explain why nematode diversity at VB2, but not at MAP, seemed to have recovered from the turbidite event but the sedimentchange explanation seems more plausible at present.

The data are sufficiently strong to propose the hypothesis that deep-sea nematodes show a modest but statistically significant change in diversity when exposed to large-scale physical disturbance. These data suggest that nematodes appear more robust to such disturbance than macrofauna, especially polychaetes. Evidence from shallow water studies is consistent with this interpretation. The most plausible explanation for the lower diversity at the MAP turbidite site is the long-term change in sediment characteristics at this site but, with the current state of knowledge, lowdispersal ability cannot be ruled out as a mechanism.

Acknowledgements. We must thank J. D. Gage and R. M. Warwick for advice and G. L. J. Paterson for critically reading the manuscript. The authors gratefully acknowledge sound council from anonymous referees.

\section{LITERATURE CITED}

Austen MC, Widdicombe S, Villano-Pitacco N (1998) Effects of biological disturbance on diversity and structure of meiobenthic nematodes communities. Mar Ecol Prog Ser 174:233-246

Boucher G, Lambshead PJD (1995) Ecological biodiversity of marine nematodes in samples from temperate, tropical, and deep-sea regions. Conserv Biol 9:1594-1604

Bowles FA, Fleischer P (1985) Orinoco and Amazon River 
sediment input into the eastern Caribbean basin. Mar Geol 68:53-72

Cole KH, Guinasso NL, Richardson MD, Johnson JW, Schink DR (1985) Uranium and thorium series isotopes in recent sediments of the Venezuela Basin, Caribbean sea. Mar Geol 68:167-185

de Lange GJ, Jarvis I, Kuijpers A (1987) Geochemical characteristics and provenance of late Quaternary sediments from the Madeira Abyssal Plain, N Atlantic. In: Weaver PPE, Thomson J (eds) Geology and geochemistry of abyssal plains. Blackwell Scientific Publications, Oxford, p 147-165

Etter RJ, Grassle JF (1992) Patterns of species diversity in the deep sea as a function of sediment particle size diversity. Nature 360:576-579

Gage JD, May RM (1993) A dip into the deep seas. Nature 365:609-610

Glover AG, Paterson GLJ, Bett B, Gage J, Sibuet M, Sheader M, Hawkins L (2001) Patterns in polychaete abundance and diversity from the Madeira Abyssal Plain, northeast Atlantic. Deep-Sea Res 48:217-238

Gray JS (2000) The measurement of marine species diversity, with an application to the benthic fauna of the Norwegian continental shelf. J Exp Mar Biol Ecol 250:23-49

Hollister CD, Nowell ARM (1991) HEBBLE epilog. Mar Geol 99:445-460

Hurlbert SH (1971) The non-concept of species diversity: a critique and alternative parameters. Ecology 52:577-586

Huston MA (1994) Biological Diversity. Cambridge University Press, Cambridge

Kinder TH, Heburn GW, Green AW (1985) Some aspects of the Caribbean circulation. Mar Geol 68:25-52

Lambshead, PJD, Elce BJ, Thistle D, Eckman JE, Barnett PRO (1994) A comparison of the biodiversity of deep-sea marine nematodes from three stations in the Rockall Trough, northeast Pacific. Biodivers Lett 2:95-107

Lambshead PJD, Tietjen J, Ferrero T, Jensen P (2000). Latitudinal diversity gradients in the deep sea with special reference to North Atlantic nematodes. Mar Ecol Prog Ser 194:159-167

Paterson GLJ, Lambshead PJD (1995) Bathymetric patterns of polychaete diversity in the Rockall Trough, northeast Atlantic. Deep-Sea Res 42:1199-1214

Rice AL, Lambshead PJD (1994) Patch dynamics in the deepsea benthos: the role of a heterogeneous supply of organic

Editorial responsibility: John Gray (Contribution Editor), Hong Kong, ROC matter. In: Giller PS, Hildrew AG, Raffaelli DG (eds) Aquatic ecology: scale, pattern and process. 34th Symp Brit Ecol Soc. Blackwell Scientific Publications, Oxford, p 469-499

Richardson MD, Young DK (1987) Abyssal benthos of the Venezuela Basin, Caribbean Sea: standing stock considerations. Deep-Sea Res 34:145-164

Sanders HL (1968) Marine benthic diversity: a comparative study. Am Nat 102:243-82

Santos V, Billett DSM, Rice AL, Wolff GA (1994) Organic matter in deep-sea sediments from the Porcupine Abyssal Plain in the northeast Atlantic Ocean, I-Lipids. Deep-Sea Res 41:787-819

Schratzberger M, Warwick RM (1998) Effects of physical disturbance on nematode communities in sand and mud: a microcosm experiment. Mar Biol 130:643-650

Thistle D, Sherman KM (1985) The nematode fauna of a deepsea site exposed to strong near-bottom currents. Deep-Sea Res 32:1077-1088

Thistle D, Yingst JY, Fauchald K (1985) A deep-sea benthic community exposed to strong near bottom currents on the Scotian Rise (Western Atlantic). Mar Geol 66:91-112

Thistle D, Lambshead PJD, Sherman KM (1995) Changes in proportional abundance of nematode buccal cavity and tail-shape groups in three different regions of the North Atlantic deep sea. Vie Milieu 45:107-115

Thomson J, Weaver PPE (1994) An AMS radiocarbon method to determine the emplacement time of recent deep-sea turbidites. Sediment Geol 89:1-7

Tietjen JH (1976) Distribution and species diversity of deepsea nematodes off North Carolina. Deep-Sea Res 23: 755-768

Tietjen JH (1984) Distribution and species diversity of deepsea nematodes in the Venezuela Basin. Deep-Sea Res 31: $119-132$

Tietjen JH (1989) Ecology of deep-sea nematodes from the Puerto Rico Trench area and Hatteras Abyssal Plain. Deep-Sea Res 36:1579-1594

Weatherly GL, Kelley EA Jr (1982) Too cold. Bottom layers at the base of the Scotian Rise. J Mar Res 40:985-1012

Weaver PPE, Rothwell RG (1987) Sedimentation of the Madeira Abyssal Plain over the last 300 years. In: Weaver PPE, Thomson J (eds) Geology and geochemistry of abyssal plains. Blackwell Scientific Publications, Oxford, p 71-86

Submitted: April 28, 2000; Accepted: September 20, 2000 Proofs received from author(s): March 8, 2001 